\title{
ASSESSMENT OF DAILY INTAKE OF ARSENIC AND ASSOCIATED HEALTH RISKS FOR CHILDREN
}

\author{
IMOKHAI T. TENEBE ${ }^{1,2}$, PRAISEGOD C. EMENIKE ${ }^{1}$, DIWA I. DANIEL ${ }^{1}$, AIKUOLA OLUMUYIWA ${ }^{3}$, \\ CHUKWUKA CHIBUIKE DANIEL ${ }^{1}$, OLUNUGA OLUWATOSIN GIDEON ${ }^{1}$, \\ ABRAHAM CHUKWUEBUKA ${ }^{1}$, UMEH CHUBUIKE ${ }^{1} \&$ EGBU-ETU EMMANUEL ETU $^{4}$ \\ ${ }^{1}$ Department of Civil Engineering, Covenant University, Nigeria \\ ${ }^{2}$ Ingram School of Engineering, Texas State University, USA \\ ${ }^{3}$ Federal Polytechnic Ilaro, Nigeria \\ ${ }^{4}$ Department of Industrial and Systems Engineering, Wayne State University, USA
}

\begin{abstract}
Surface water is a major source of heavy metal contamination due to land use variabilities and can impair the health status of humans especially children when consumed. This study investigated the arsenic concentration in surface water of River Balogun in south-west Nigeria. Fifty-one samples were collected from 17 points along the river and were examined using inductively coupled plasma optical emission spectrophotometer (ICP-OES) for arsenic concentration levels and the potential of a risk due to prolonged exposures in children using average daily dose, and hazard quotient (HQ) indices were estimated. From this study, it revealed that the mean daily intake concentrations of arsenic for children were within the range of $0.0034-0.0068 \mathrm{mg} / 1$ and these values were below the standards for the World Health Organization. However, long term exposures could be injurious to the health of children as the HQ values were greater than one for all 51 samples. Therefore, continuous human health risk assessment, sensitization on the adverse effects on the overuse of agrochemicals in farms surrounding the rivers, intensified ecosystem services as well as best management practices for improvement of surface water in the region need to be adopted. Furthermore, elaborating on the dangers of high arsenic in water can also be a strategy in preventing children and other population groups from consuming contaminated surface waters in that vicinity.
\end{abstract}

Keywords: risk assessment, arsenic, pollution, heavy metals, dispersion, hazard quotient.

\section{INTRODUCTION}

Access to safe water is germane and this has led to the Sustainable Development Goals (SDGs) Target 6, Goal 6 which aimed at providing cheap, safe and less polluted water for all [1], [2]. Rain-harvested, surface, sachet waters are some of the sources where water can be assessed. However, getting this water free from chemical or bacteriological pollution is still very difficult especially in developing nations. Several reports have revealed the chemical toxicity levels of heavy metals at significant levels in some of these water sources in an alarming rate [3]-[5]. The reasons for this pollution levels may be due to land use and poor hygiene as there is a strong significant relationship between the environment and the pollution status of water bodies or sources [6]-[8] as well as lack of consciousness and convincing awareness from the inhabitants and relevant agencies. These metals can cause several health effects that can reduce human efficiency at the least and may result in death at worst. Some of these adverse effects have been well reported in the literature [9]-[11]. Arsenic (As), which is one of these heavy metals which are found naturally is of great concern for public health because of its effects on the human health such as dermal and cardiovascular diseases, skin and bladder cancer, diabetes mellitus among others [12], [13]. Its presence in food proves that it is usually accumulated from the environment [14]. In groundwater, As is found mainly in inorganic forms [15] which are considered much more toxic than the organic one [16]. It is estimated that close to 140 million people globally are exposed to inorganic As which are primarily ingested by consuming unregulated contaminated water [17]. Thus, As 
in the drinking water sources, be it ground or surface waters, is of important concern due to its associated health risk [18]. In the light of this, this study investigated the pollution level of As in surface water of River Balogun, located in Ota. This river is surrounded by industries and it is well utilized by the inhabitants for domestic and recreational purposes. Due to the open nature of the river, it is mostly used as a carrier of unwanted substances with the believe that with dilution and dispersion, these inherent pollutants concentration may be reduced [19]. Therefore, in this paper, we examine the health risk linked with surface water daily consumption of As to children.

\section{METHOD AND MATERIAL}

\subsection{Study area}

River Balogun situated around Ado-Odo/Ota local government area in south-west Nigeria, with an area of $1,460 \mathrm{~km}^{2}$. It lies between latitude $6^{\circ} 40^{\prime} 58.52^{\prime \prime} \mathrm{N}-6^{\circ} 41^{\prime} 23.92$ 'N $\mathrm{N}$ and longitude $3^{\circ} 8^{\prime} 53.87^{\prime \prime} \mathrm{E}-3^{\circ} 8^{\prime} 57.86^{\prime} \mathrm{E}$ and is a tributary of the River Atuwara. The study area is densely populated with informal settlements situated close to the study area. River Balogun traverses across villages, providing the needed water and economic activities to the surrounding villages such as dredging, irrigation farming and fishing. River Balogun's water is essentially important for the ecosystem, health and sustained economic activities such as agriculture and supply of drinking water to people, which requires continuous environmental surveillance and proper industrial waste management.

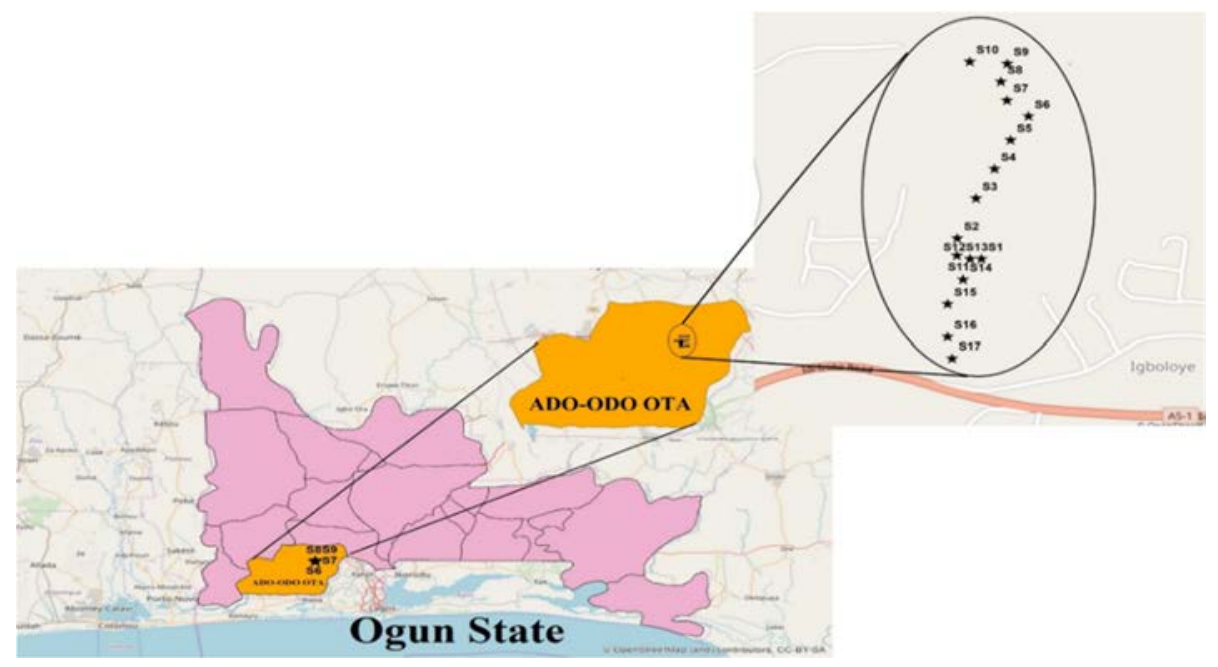

Figure 1: A map showing River Balogun at Ota, Ogun State [10].

\subsection{Sampling collection and procedures}

Fifty-one (51) water samples from seventeen (17) stations were collected from the river using a well labelled High density polyethene bottle. The samples collected were iced in a cooler at $4^{\circ} \mathrm{C}$. Thereafter, these samples were sent to the International Institute for Tropical Agriculture, Ibadan, Nigeria, for chemical analysis. The samples were analysed for As using Inductively Coupled Plasma-Optical Emission Spectrometry (ICP-OES). 


\subsection{Health risk assessment}

Generally, risk assessment is a function of hazard while exposure is the process of estimating the probability of occurrence of an event and the probable magnitude of adverse health effects produced over a specified time period [20]. Human health risk assessment is considered as the characterization of the potential adverse health effects of humans due to exposure to environmental hazards [21]. This paper estimated the average daily dose (ADD) expected for the intake of As using the following eqn (1), while cancer risk and hazard quotient were estimated using (2) and (3) respectively

$$
\mathrm{ADD}=\mathrm{C} \times \mathrm{IR} \times \mathrm{ED} \times \mathrm{EF} / \mathrm{BW} \times \mathrm{AT},
$$

where ADD is the average daily dose ( $\mathrm{mg} / \mathrm{kg}$-day), $\mathrm{C}$ is the concentration of the heavy metal in stream water $(\mathrm{mg} / \mathrm{l})$, IR is the ingestion rate per unit time (L/day), ED is the exposure duration (years), EF is the exposure frequency (days/year), BW is body weight (kg), AT is the average time (years), with their values obtained from literatures [22]-[24].

The cancer risk was calculated as outlined by [21]:

$$
\text { Cancer risk }=\mathrm{ADD} \times \mathrm{CSF} \text {, }
$$

where $\mathrm{ADD}=$ average daily doses ( $\mathrm{mg} / \mathrm{kg}$-day); $\mathrm{CSF}=$ cancer slope factor ( $\mathrm{mg} / \mathrm{kg}$-day).

The calculated ADD and cancer risk are as presented in Fig. 2.

$$
H Q_{\text {ingestion }}=\frac{A D D_{\text {ingestion }}}{R D_{\text {ingestion }}} \text {. }
$$

\section{RESULTS AND DISCUSSION}

The ADD values for As are presented in Fig. 2. For children, the daily intake for As was between range of $0.0034-0.0068 \mathrm{mg} / \mathrm{kg}$-day. According to the results, the level of As, $6.799 \mathrm{E}-03 \mathrm{mg} / \mathrm{kg}$-day for children in Station 1 and Station 2 respectively appeared high, but the highest values of $8.500 \mathrm{E}-03$ were recorded at stations $11,12,13,15,16$ and 17 for

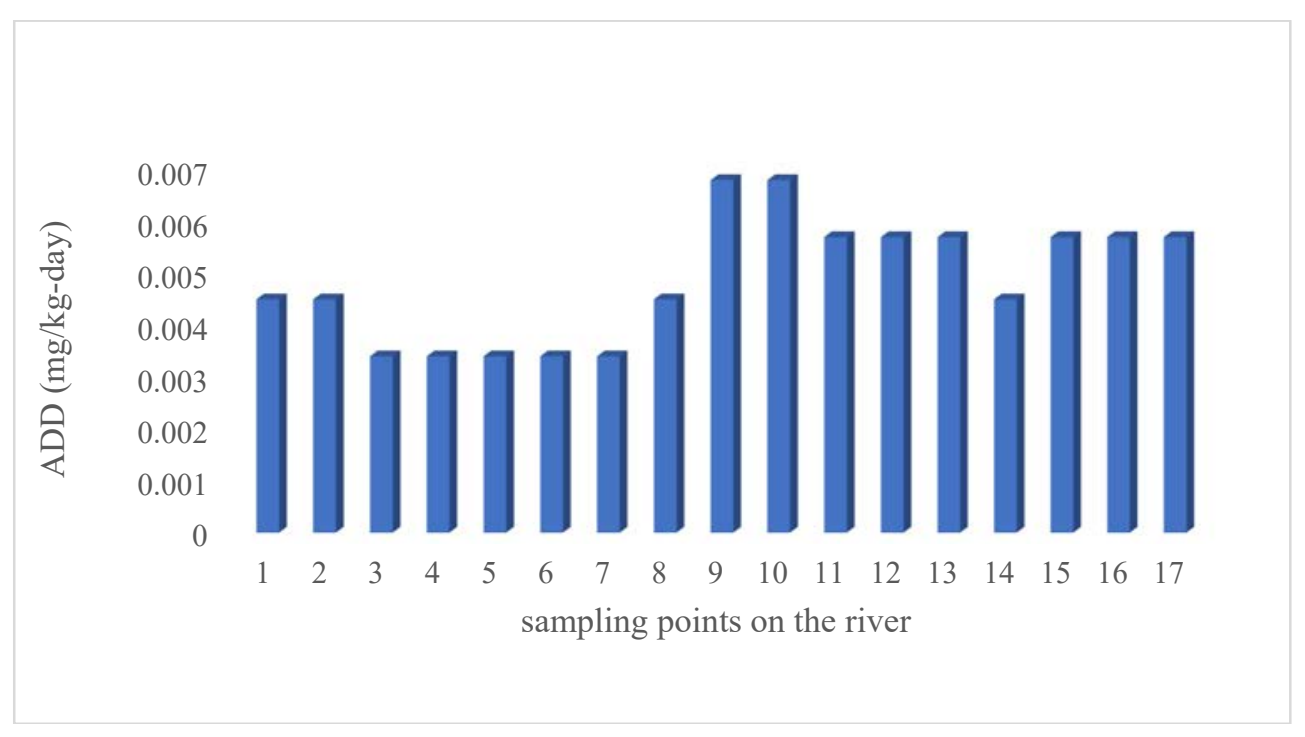

Figure 2: Graphical representation of average daily intake of As in children. 
children. Furthermore, due to the measured results and importance of the ELCR (excess lifetime cancer risk) level - which is the threat to human health, it becomes highly important that drinking water control and quality in that region is a necessity specially to protect the children. In addition, results revealed that River Balogun water may pose a high risk, when compared with the water quality guidelines of USEPA [25], which is fixed at $10 \mu \mathrm{g} / \mathrm{l}$. Consequently, cancer risk assessment of the study area suggested that there is high health risk due to the As contamination. As was reported to be detrimental to the central nervous system and cognitive development in children [26]. It was also found to accumulate in fingernails and hair [27] which can later find its way into our body. Therefore, it implied that using this water either for ingestion or recreation is dangerous.

Fig. 3 shows the HQ of As consumption for children in River Balogun at different sampling stations. The HQ values recorded ranged from $11.33-22.67 \mathrm{mg} / \mathrm{l}$. The highest level was at Stations 9 and 10 which recorded $22.67 \mathrm{mg} / \mathrm{l}$ as against World Health Organization [28] standard of $1.00 \mathrm{mg} / \mathrm{l}$. This result indicates that children ingest water that is significantly polluted with As (about 22 times more than the threshold value) and appeared to be at high risk for carcinogenic effects in the long run. In other stations, high As levels were equally recorded. Specifically, stations 11-16, with values as $19 \mathrm{mg} / 1$ while $15 \mathrm{mg} / \mathrm{l}$ was recorded in stations 1 and 2. Furthermore, $11 \mathrm{mg} / 1$ were recorded at stations 3, 4, 5, 6 and 7 as well. This may be due to over application of fertilizers and poor agricultural practices within the study area as reported in similar studies elsewhere [29], [30]. These results agreed with the findings of [31] in Taiwan where the HQ values were $19.3 \mathrm{mg} / \mathrm{g}$ revealing threat to life of the population. Subsequently, when children ingest water polluted by As, they become more exposed to all kinds of cancers especially cancer related to the skin, kidney and bladder which are classified as carcinomas [32]. As also known to speed up cell division which leads to all kinds of health complications in human. In addition, retardation of time required for enzymes to repair DNA damage during DNA replication will occur and the likelihood of genetic misleading may be the consequence.

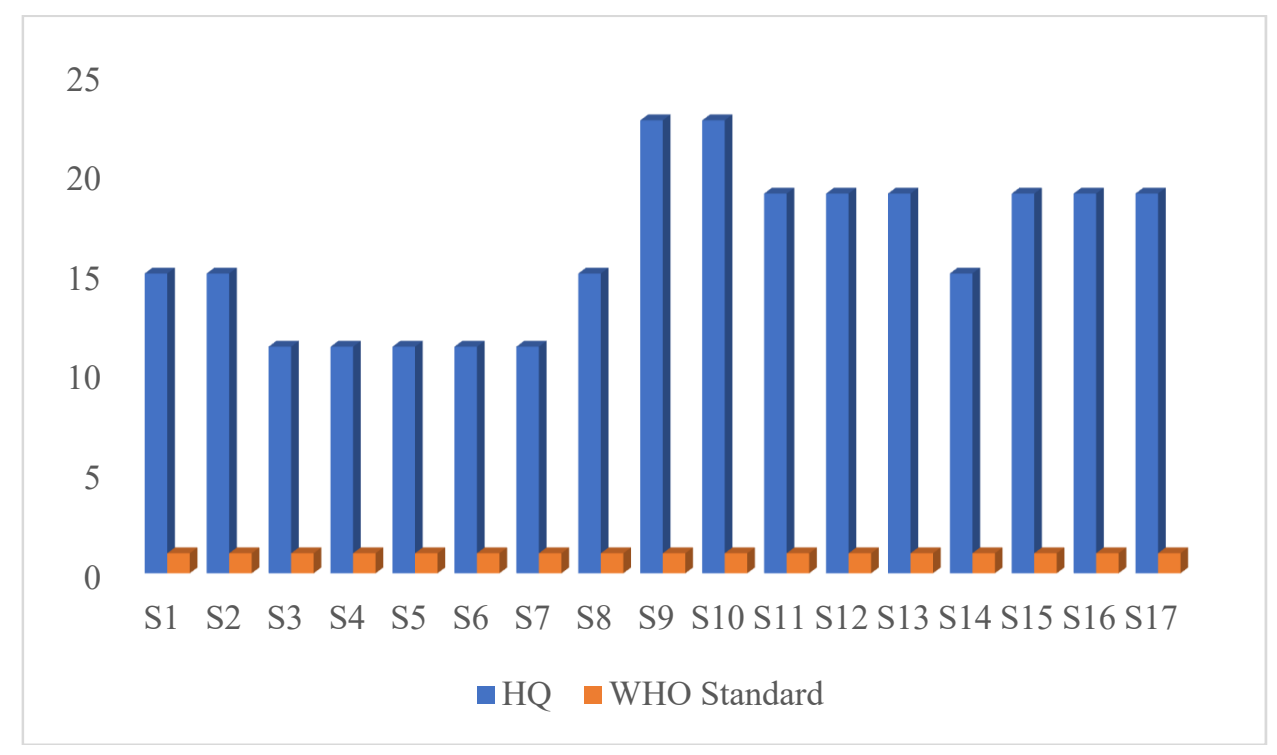

Figure 3: Graphical representation of the hazard quotient (As for children) against the World Health Organization standard. 


\section{CONCLUSION}

The ADD values and cancer risks for As were highest in Stations 11, 12, 13, 15, 16, and 17 for children, which can pose a threat to human life. Due to the carcinogenic tendency of As over long periods of exposure and the risk to life and health, it is important to control the presence of As in the river Balogun as the present status showed a significant health risk to children. Prevention of exposure to As in drinking water is a major strategy for reducing the incidence of cancer due to As ingestion. In addition, regular monitoring of contamination levels of heavy metals and imbibing good sanitation practises and convincing awareness to inhabitants on the dangers of As pollution to children would boost general water quality of the river as well as other water sources. In addition, improving ecosystem services around rivers in general by creating wetlands or riparian buffers which should prevent agricultural runoff from gaining easy entrance into the river would serve as some kind of best management practices to be swiftly adopted.

\section{ACKNOWLEDGEMENTS}

We are very grateful to Covenant University and Texas State University for their sponsorship.

\section{REFERENCES}

[1] UNDESA, Sustainable development goals. https://sustainabledevelopment.un.org/ sdgsproposal. Accessed on: 7 Nov. 2015.

[2] Emenike, C.P., Tenebe, I.T., Omole, D.O., Ndambuki, J.M., Ogbiye, A.S. \& Sojobi, A., Application of water recovery option for agricultural use in developing countries: Case study of a Nigerian community. Conference on International Research on Food Security, Natural Resource Management and Rural Development, 2015.

[3] Chinedu, S., Nwinyi, O., Oluwadamisi, A. \& Eze, V., Assessment of water quality in Canaanland, Ota, Southwest Nigeria. Agriculture and Biology Journal of North America, 2(4), pp. 577-583, 2011.

[4] Anake, W., Benson, N., Akinsiku, A., Ehi-Eromosele, C. \& Adeniyi, I., Assessment of trace metals in drinking water and groundwater sources in Ota, Nigeria. International Journal of Scientific and Research Publications, 4, pp. 1-4, 2014.

[5] Emenike, P.C., Tenebe, T.I., Omeje, M. \& Osinubi, D.S., Health risk assessment of heavy metal variability in sachet water sold in Ado-Odo Ota, South-Western Nigeria. Environ. Monit. Assess., 189, p. 480, 2017. DOI: 10.1007/s10661-017-6180-3.

[6] Tenebe, I.T., Emenike, C.P., Ogbiye, A.S., Ngene, B.U., Omeje, M. \& Olatunji, O.O., A laboratory assessment of the effect of varying roughness on dissolved oxygen using error correction method. Cogent Engineering, pp. 1-11, 2018.

[7] Tenebe, I.T., Ogbiye, A.S., Omole, D.O. \& Emenike, P.C., Estimation of longitudinal dispersion co-efficient: A review. Cogent Engineering, 3, 2016.

DOI: $10.1080 / 23311916$.

[8] Emenike, P., Omole, D., Ngene, B. \& Tenebe, I., Potentiality of agricultural adsorbent for the sequestering of metal ions from wastewater. Global Journal Environmental Science and Management, 2, pp. 411-442, 2016.

[9] Muhammad, N., Bangush, M. \& Khan, T., Microbial contamination in well water of temporary arranged camps: A health risk in northern Pakistan. Water Quality, Exposure and Health, 4(4), pp. 209-215, 2012. DOI: 10.1007/s12403-012-0080-0.

[10] Tenebe, I.T., Emenike, C.P. \& Chukwuka, D., Prevalence of heavy metals and computation of its associated risk in surface water consumed in Ado-Odo Ota, SouthWest Nigeria. Human and Ecological Risk Assessment: An International Journal, pp. 1-23, 2018. DOI: 10.1080/10807039.2018.1454824. 
[11] Emenike, P.C., Tenebe, I.T. \& Jarvis, P., Fluoride contamination in groundwater sources in Southwestern Nigeria: Assessment using multivariate statistical approach and human health risk. Ecotoxicol. Environ. Saf., 2018. DOI: 10.1016/j.envsoft.2004.03.001.

[12] Eblin, K.E. et al., Arsenite and monomethylarsonous acid generate oxidative stress response in human bladder cell culture. Toxicology and Applied Pharmacology, 217(1), pp. 7-14, 2006.

[13] Sun, Q. et al., Improved diffusive gradients in thin films (DGT) measurement of total dissolved inorganic arsenic in waters and soils using a hydrous zirconium oxide binding layer. Analytical Chemistry, 86(6), pp. 3060-3067, 2014.

[14] Roychowdhury, T., Uchino, T., Tokunaga, H. \& Ando, M., Survey of arsenic in food composites from an arsenic-affected area of West Bengal, India. Food and Chemical Toxicology, 40, pp. 1611-1621, 2002.

[15] Tuzen, M., Citak, D., Mendil, D. \& Soylak, M., Arsenic speciation in natural water samples by coprecipitation-hydride generation atomic absorption spectrometry combination. Talanta, 78(1), pp. 52-56, 2009.

[16] Brahman, K.D., Kazi, T.G., Afridi, H.I., Naseem, S., Arain, S.S. \& Ullah, N., Evaluation of high levels of fluoride, arsenic species and other physicochemical parameters in underground water of two sub districts of Tharparkar, Pakistan: A multivariate study. Water Research, 47(3), pp. 1005-1020, 2013.

[17] States, J.C., Barchowsky, A., Cartwright, I.L., Reichard, J.F., Futscher, B.W. \& Lantz, R.C., Arsenic toxicology: translating between experimental models and human pathology. Environ. Health Perspect., 2011. DOI: 10.1289/ehp.1103441.

[18] Sorg, T.J., Chen, A.S.C. \& Wang, L., Arsenic species in drinking water wells in the USA with high arsenic concentrations. Water Research, 48(1), pp. 156-169, 2014.

[19] Tenebe, I.T., Ogbiye, A.S., Omole, D.O. \& Emenike, P.C., Modelling and sensitivity analysis of varying roughness effect on dispersion coefficient: A laboratory study. Desalination and Water Treatment, 87, pp. 1-7, 2017. DOI: 10.5004/dwt.2017.21298.

[20] Wongsasuluk, P., Chotpantarat, S., Siriwong, W. \& Robson, M., Heavy metal contamination and human health risk assessment in drinking water from shallow groundwater wells in an agricultural area in Ubon Ratchathani province, Thailand. Environ. Geochem. Health, 36, pp. 169-182, 2014.

[21] USEPA, Waste and cleanup risk assessment. www2.epa.gov/risk/waste-and-cleanuprisk-assessment. Accessed on: Dec. 2017.

[22] USEPA, United States Environmental Agency Risk Assessment Guidance for Superfund, Volume 1: Human Health Evaluation Manual (Part A), Interim Final Office of Emergency and Remedial Response, EPA/540/7-89/002, 1989.

[23] USEPA, United States Environmental Protection Agency, Human Health Evaluation Manual, Supplemental Guidance, Standard Default Exposure Factors, OSWER Dir. 9285, 6-03, 1991.

[24] Van Graan, A.E., Bopapa, M., Phooko, D., Bourne, L. \& Wright, H.H., Drink lots of clean safe water: A food-based dietary guideline for South Africa. S. Afr. J. Clin. Nutr., 26(3), pp. S77-S86, 2013.

[25] USEPA, Integrated risk information system (IRIS), United States Environmental Protection Agency. www.Epa.Gov/irrris/index.infml.

[26] Rosado, J.L. et al., Arsenic exposure and cognitive performance in Mexican schoolchildren. Environ. Health Perspect., 115(9), pp. 1371-1375, 2007. 
[27] Choong, T.S.Y., Chuah, T.G., Robiah, Y., Koay, F.L.G., Azni, I., Arsenic toxicity, health hazards and removal techniques from water: An overview. Desalination, 217, pp. 139-166, 2007.

[28] World Health Organization, Guideline for Drinking-water Quality, 3rd ed. incorporating 1st and 2nd Agenda, Vol. 1: Recommendations, Geneva, 668 pp., 2008.

[29] Tsuda, T. et al., Historical cohort studies in 3 arsenic poisoning areas in Japan. Applied Organometallic Chemistry, 6, pp. 333-341, 1992.

[30] Christ, O., Charalambous, M., Aletrari, C., Nicolaidou Kanari, M., Petronda, P., Ward, N.I., Arsenic concentrations in ground waters of Cyprus. J. Hydrol., 468(469), pp. 94100, 2012.

[31] Han, B.-C., Jeng, W.-L., Hung, T.-C., Ling, Y.-C., Shieh, M.-J. \& Chien, L.-C., Estimation of metal and organochlorine pesticide exposures and potential health threat by consumption of oysters in Taiwan. Environ. Pollut., 109, pp. 147-156, 2000.

[32] Lamm, S.H., Engel, A., Penn, C.A., Chen, R. \& Feinleib, M., Arsenic cancer risk confounder in Southwest Taiwan data set. Environ. Health Perspect., 114, pp. 10771082, 2006. 